\title{
Water Erosion in the Donga Soils in Subhumid Zone in West Africa
}

\author{
Julien Avakoudjo ${ }^{*}$, Félix Alladassi Kouelo², Valentin Missiako Kindomihou1, \\ Pierre Irénikatché Akponikpe ${ }^{3}$, Anastase Hessou Azontonde ${ }^{4}$, Brice Augustin Sinsin', \\ Tobi Moriaque Akplo², Mahugnon Socrate Agonvinon²
}

${ }^{1}$ Laboratory of Applied Ecology of the Faculty of Agronomic Sciences of the University of Abomey-Calavi, Abomey-Calavi, Benin ${ }^{2}$ Laboratory of Soil Microbiology and Microbial Ecology, Faculty of Agronomic Sciences of University of Abomey-Calavi, Abomey-Calavi, Benin ${ }^{3}$ Research Unity of Soil Physic and Environmental Hydraulic, Faculty of Agronomy, University of Parakou, Parakou, Benin ${ }^{4}$ Laboratory for Soil Science, Water and Environment, Agricultural Research Centre of Agonkanmey, National Institute for Agricultural Research of Benin, Abomey-Calavi, Benin

Email: ^felix.kouelo@gmail.com

How to cite this paper: Avakoudjo, J., Kouelo, F.A., Kindomihou, V.M., Akponikpe, P.I., Azontonde, A.H., Sinsin, B.A., Akplo, T.M. and Agonvinon, M.S. (2020) Water Erosion in the Donga Soils in Subhumid Zone in West Africa. Journal of Environmental Protection, 11, 1073-1088. https://doi.org/10.4236/jep.2020.1112068

Received: November 12, 2020

Accepted: December 27, 2020

Published: December 30, 2020

Copyright $\odot 2020$ by author(s) and Scientific Research Publishing Inc. This work is licensed under the Creative Commons Attribution International License (CC BY 4.0).

http://creativecommons.org/licenses/by/4.0/

\begin{abstract}
The runoff and soil loss were assessed in situ at the scale of $2.12 \mathrm{~m}^{2}$ plots during the rainy season of 2010 to better understand the determinants and magnitude of the massive soil loss and land subsidence (donga) in the sub-humid zone of Africa in Karimama, North Benin. The experimental design was a split plot with two factors: the topography in 3 modalities (upstream, center and downstream of the donga) was assigned as main plot factor and the degree of degradation of dongas in 2 modalities (beginner dongas and advanced dongas) was assigned as subplot factor. Runoff water was collected through a storage system composed of two tanks. Data were collected on 36 plots (9 plots per donga $\times 4$ dongas). The runoff varies significantly from one site to another for the rainy episode of October 10, 2010. It is twice as high in land use areas $(5.87 \mathrm{~mm})$ as in W Park $(2.32 \mathrm{~mm}$; 1.s.d. $=1.81 \mathrm{~mm})$. From upstream to downstream, runoff and soil loss increased from $2.4 \mathrm{~mm}$ to $85.3 \mathrm{~mm}$ and $80 \mathrm{~g} \cdot \mathrm{m}^{-2}$ to $197 \mathrm{~g} \cdot \mathrm{m}^{-2}$, respectively. Runoff is high in the early dongas $(7.60 \mathrm{~mm})$ and low in the advanced dongas $(5.68 \mathrm{~mm})$ in contrast to lower soil loss in the early dongas $\left(34 \mathrm{~g} \cdot \mathrm{m}^{-2}\right)$ and high in the advanced dongas $\left(237 \mathrm{~g} \cdot \mathrm{m}^{-2}\right)$. The low value of soil loss with respect to the magnitude of the phenomenon suggests the probable occurrence of other soil loss mechanisms to be elucidated.
\end{abstract}

\section{Keywords}

W National Park, Land Use Areas, Dongas, Runoff, Erosion, Soil Loss 


\section{Introduction}

Natural and anthropogenic factors induce changes in the land use areas, reducing plant cover, biological diversity and non-timber forest products. Their combination contributes to deforestation, degradation and desertification [1]. Water erosion is mainly due to water runoff on the "bare" soil surface [2]. The problem is more pronounced in marginal lands due to intensive cultivation and overpopulation [3]. Water erosion, on a global scale, is the main degradation process of agricultural soils [4]. Although runoff and erosion are doubly perceived as agents of degradation and indicators of imbalance between the environment and its farming system, they are not the primary cause but can accelerate degradation [5]. Soil degradation threatens agricultural production and food security in Sub-Saharan Africa [6]. Dry savannah areas face the same environmental problems where soil erosion and depletion seriously threaten savannah productivity under $80 \%$ of degraded land [7].

In north-western Benin, land erosion and degradation are characterized by the massive loss of land known as "dongas" [8] [9], which induces serious threats to the habitat and reduces the availability of fodder in the Park. In fact, in the district of Karimama, where $92.3 \%$ of the land is occupied by the W National Park, dongas are developing and progressing at a worrying rate. In its surrounding areas, farmers (89.71\%) face erosion in their fields [9]. Understanding the erosion process and its impact is necessary to model the spatial and temporal extent of erosion in order to limit its evolution and control it [8]. Karimama dongas have been documented on their typology and constituent plant groupings [8] and on their specific diversity [9]. Recently, [10] uses local perceptions of farmers to identify soil erosion as well as the main causes and factors and how they contribute to improve knowledge on the phenomenon of "dongas". The results show from the rationality rate in the local perception of causes and factors of change, that deforestation is most pronounced in Karimama, and mainly favored by slope, runoff, low vegetation cover and unsustainable land tenure practices. A better understanding of the causes of these various forms of erosion and land degradation and their mechanisms is essential for the development and implementation of rehabilitation strategies.

The present study aims at quantifying soil erosion and runoff in the dongas of the W National Park in the district of Karimama and its peripheral zone. Specifically, what is the impact of the site, the topography and the degree of degradation of the dongas on the erosion and runoff in this environment? The evaluation of erosion and runoff will contribute to circumscribe the parameters and determining factors necessary to predict the phenomenon, and to succeed in soil restoration and rehabilitation of degraded ecosystems in the Sudano-Sahelian zone of Benin.

\section{Materials and Methods}

\subsection{Experimental Site}

The dongas studied in the subhumid zone precisely in the North of Benin in the 
district of Karimama, are distributed in the $\mathrm{W}$ National Park and on the land use areas. The district of Karimama $\left(11^{\circ} 26-12^{\circ} 26\right.$ latitude N; $2^{\circ} 17$ - $3^{\circ} 05$ longitude E) is bounded by the Niger River at north, by the District of Banikoara the south-west, by the District of Kandi at south-east, by the District of Malanville at east and by the Republic of Burkina-Faso at west (Figure 1). The climate is Sudano-Sahelian with a single rainy season lasting 4 to 6 months and a dry season lasting 6 to 8 months. The average rainfall is 750 to $900 \mathrm{~mm}$. The soils are of tropical ferruginous types; hydromorphic soils are found along the Niger River. Population density (49 inhabitants per $\mathrm{km}^{2}$ ) is higher than in Borgou (20 inhabitants per $\mathrm{km}^{2}$ ) and Alibori (28 inhabitants per $\mathrm{km}^{2}$ ) [11]. This high density partly explains the strong anthropogenic pressures on natural resources and particularly on land.

\subsection{Experimental Design}

The experimental design used was a split plot (RCB) with two factors (topography and degree of donga degradation). The blocks consist of three plots installed from the Upstream to the Downstream of the donga. The experiment was carried out in two strata or sites (whole plot): the W National Park and the land use area. The three levels of slope (Upstream, Center and Downstream of the donga) are the modalities of the topography (main plot factor). The subplot factor, which is the degree of degradation of the dongas, includes two types of dongas that have been chosen according to the degree of erosion: shallow dongas (diameter between 10 and $50 \mathrm{~m}$ and depth less than $1 \mathrm{~m}$ ) and advanced dongas

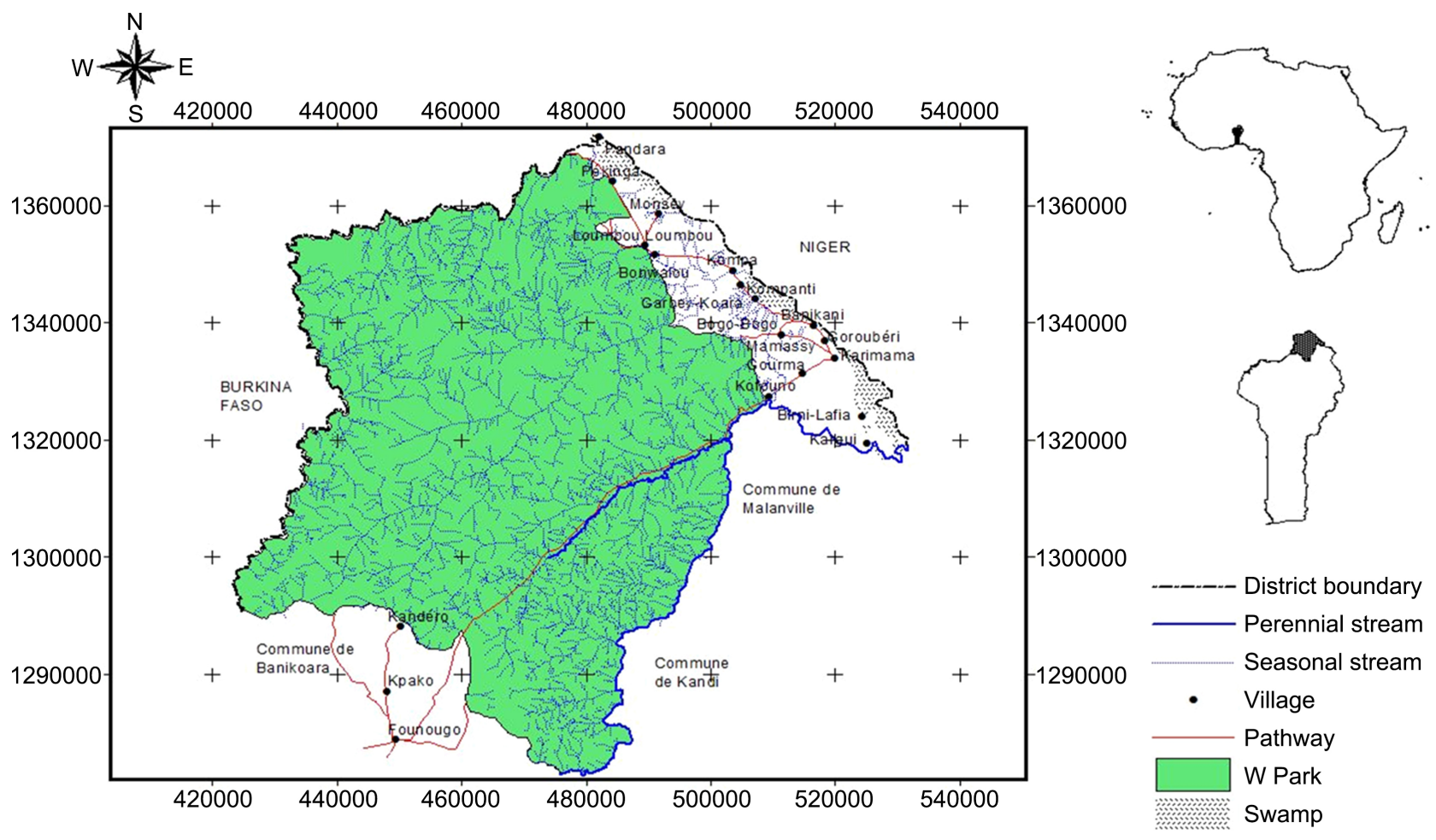

Figure 1. Studied area. 
(diameter $>50 \mathrm{~m}$ and depth $>1 \mathrm{~m}$ ). Two dongas were chosen per site: the beginner donga from Baru and the advanced donga from Kargui in the village area and the beginner donga $\mathrm{DP}_{1}$ and the advanced donga $\mathrm{DP}_{2}$ in the $\mathrm{W}$ Park.

In situ data (mean slope and permeability were collected in experimental plots within each donga [12] [13]. Erosion plots are repeated three times in each donga. A total of 36 deviation plots (9 plots/dongas) were considered.

The experimental plots were delimited by sheet metal (Figure 2). They consist of a rectangular plot $(1 \mathrm{~m} \times 2 \mathrm{~m})$ extended downstream by a trapezoidal one [large base $=1 \mathrm{~m}$; small base $=0.1 \mathrm{~m}$ (funnel hole) and height $=0.22 \mathrm{~m}$ ]. The sheets are sunk $10 \mathrm{~cm}$ into the ground, so as to have an overflow of $20 \mathrm{~cm}$. The center of the downstream width of the device is a collecting gutter in the form of a collector. Runoff water was collected through the gutter at the plot outlet. Each plot covers $2.12 \mathrm{~m}^{2}$.

\subsection{Choice of Rain Episodes}

After each rainfall event, measurements are taken in sampled dongas to assess runoff and recorded soil losses. The rain episode common to all targeted sites and dongas was studied. In order to limit the biases related to the differences in recorded rainfall, in addition to the rainy episode of October 16, 2010 which was common to all sites and dongas, other episodes with approximate rainfall amounts or occurring in the same period when the vegetation cover is maximum, were selected and analyzed.

\subsection{Measurement of the Volume of Water Runoff and Loss of Soil}

As it was impossible to store all the run-off volume, partitioning was carried out using two 25 -litre tanks. The first was connected to the gutter by a plastic pipe (20 mm in diameter) with 20 identical holes (upper part). The second tank was connected to the first by a PVC pipe of $20 \mathrm{~mm}$ diameter. After each rainy episode, the volume of water runoff on the deviation plot is collected and measured. A homogenized sample is taken to determine the solid load. This solid load is determined by weighing 1.5 liters of homogenized runoff water and extrapolating the results to the $\mathrm{m}^{2}$ surface area.

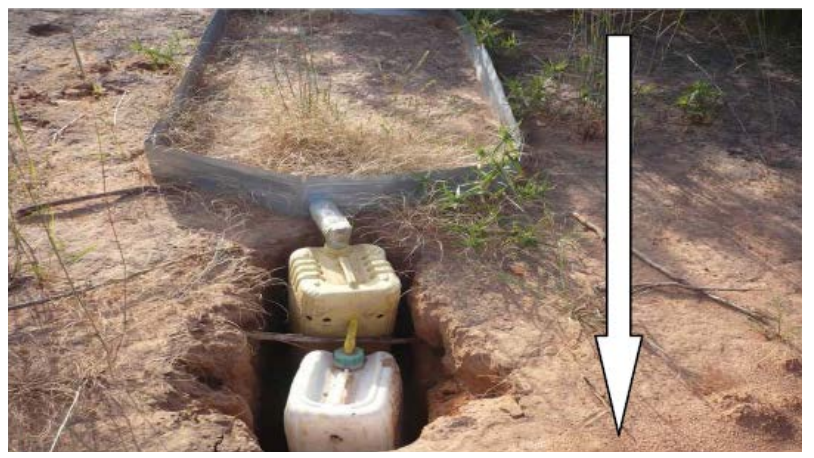

Figure 2. Experimental plots delimited by sheet metal (Erosion plots measurement design). 


\subsection{Analysis of the Data}

The runoff and soil loss data were subjected to a 3-criteria analysis of variance using GenStat-Release 4.2 software [14]. The effect of donga, site and topography factors and their interactions on runoff and erosion were analyzed at the 5\% significance level. Homogeneous groups were determined by comparing means based on the Least Significant Difference (l.s.d).

\section{Results}

\subsection{Characteristics of the Plots of Land}

Overall, the average slope was slightly higher in W Parkthan in the land use areas (3\% versus $2.4 \%$ ). Permeability varied from $0.36 \mathrm{~cm} \cdot \mathrm{h}^{-1}$ (plot 5 of the Kargui donga) to $26.64 \mathrm{~cm} \cdot \mathrm{h}^{-1}$ (plot 4 of the DP2 donga in W Park). Generally, the soils of the park are more permeable $\left(10.8 \pm 7.2 \mathrm{~cm} \cdot \mathrm{h}^{-1}\right)$ than those of the land use areas $\left(3.6 \pm 3.2 \mathrm{~cm} \cdot \mathrm{h}^{-1}\right)$.

\subsection{Characteristics of Rainfall in 2010 and Rainy Episodes}

Rainfall in 2010 indicates that the months of May, August and October are the wettest months. Similarly, $1043 \mathrm{~mm}$ of water spread over 7 months were recorded in 2010.

The number of rainy episodes varied from 30 (on the dongas of land use areas) to 32 (on the dongas of $\mathrm{W}$ Park). Thirty-nine episodes were examined with 59\% in the land use areas (Baru: $21 \%$ and Kargui: $38 \%$ ) and $41 \%$ in the dongas of Niger's $\mathrm{W}$ Park $\left(\mathrm{DP}_{1}\right.$ and $\left.\mathrm{DP}_{2}\right)$. The rainy episodes studied were: 1 ) October 16, 2010 (Land use areas with $25 \mathrm{~mm}$ of rain and W Park with $17 \mathrm{~mm}$ of rain), common to all sites and dongas sampled to compare runoff and soil loss data; 2) October 2 (with $45 \mathrm{~mm}$ of rain), October 6 (with $21 \mathrm{~mm}$ of rain) and October 11 (with $11 \mathrm{~mm}$ of rain) recorded on the dongas of W Park ( $\mathrm{DP}_{1}$ and $\mathrm{DP}_{2}$ ) to study the effects of the level of degradation and topography; 3 ) those of July 30, 2010 in Kargui (with $27.5 \mathrm{~mm}$ of rain) and September 3, 2010 in Baru (with $27 \mathrm{~mm}$ of rain), then the episodes of equal rainfall of September 20, 2010 in Kargui and August 14, 2010 in Baru (i.e., the same rainfall).

\subsection{Effects of Site, Level of Degradation and Topography}

The rainy episode of October 16 that occurred at all sites indicates runoff values that are significantly site and topography-dependent (Table 1 ). The effect of topography is more pronounced than that of site $\left[\left(\mathrm{Vr}=12.85 ; \mathrm{P}_{\mathrm{Fi}}=0.003\right)\right.$ versus $\left.\left(\mathrm{Vr}=70.96 ; \mathrm{P}_{\mathrm{Fi}}=0.014\right)\right]$. Similarly, the level of degradation and topography influence soil loss. Indeed, while the rainy episode of October 6, 2010 shows a highly significant effect of topography (Table $1, \mathrm{Vr}=10.04, \mathrm{P}_{\mathrm{Fi}}=0.007$ ) in $\mathrm{W}$ Park, the episodes of July 30 and September 3, 2010 indicate a significant effect of the level of degradation of dongas $\left(\mathrm{Vr}=48.6 ; \mathrm{P}_{\mathrm{Fi}}=0.020\right)$ in the soil. Only the level of degradation has a significant effect on runoff in Park $\mathrm{W}$ following the rainy episode of October 11, $2010\left(\mathrm{Vr}=47.8 ; \mathrm{P}_{\mathrm{Fi}}=0.020\right)$. 
Table 1. Fisher's probability (of significance) of rainfall events in 2010: Effects of site, extent of degradation and topography on runoff and soil erosion at Karimama northern Benin.

\begin{tabular}{|c|c|c|c|c|c|c|c|c|c|}
\hline Rainfall events & $\begin{array}{l}\text { Sources } \\
\text { variati }\end{array}$ & & Sites & Degradation & Topography & $\begin{array}{c}\text { Sites }^{*} \\
\text { Degradation }\end{array}$ & $\begin{array}{c}\text { Sites* } \\
\text { Topography }\end{array}$ & $\begin{array}{l}\text { Degradation }^{*} \\
\text { Topography }\end{array}$ & $\begin{array}{c}\text { Sites }^{*} \\
\text { Degradation }^{*} \\
\text { Topography }\end{array}$ \\
\hline \multirow{4}{*}{$\begin{array}{l}\text { 16/10/2010: All dongas } \\
\text { Land use area with } 25 \mathrm{~mm} \\
\text { of rainfall and W National } \\
\text { Park with } 17 \mathrm{~mm} \text { of rainfall }\end{array}$} & \multirow[b]{2}{*}{ Runoff } & $\mathrm{P}_{\mathrm{Fi}}$ & $0.014^{*}$ & $0.480 \mathrm{~ns}$ & $0.047^{*}$ & $0.617 \mathrm{~ns}$ & $0.797 \mathrm{~ns}$ & $0.0609 \mathrm{~ns}$ & $0.721 \mathrm{~ns}$ \\
\hline & & $\mathrm{Vr}$ & 71 & 0.6 & 3.7 & 0.3 & 0.2 & 0.5 & 0.3 \\
\hline & \multirow{2}{*}{ Erosion } & $\mathrm{P}_{\mathrm{Fi}}$ & $0.307 \mathrm{~ns}$ & $0.394 \mathrm{~ns}$ & $0.337 \mathrm{~ns}$ & $0.516 \mathrm{~ns}$ & $0.327 \mathrm{~ns}$ & $0.515 \mathrm{~ns}$ & $0.436 \mathrm{~ns}$ \\
\hline & & $\mathrm{Vr}$ & 1.85 & 0.91 & 1.16 & 0.51 & 1.2 & 0.69 & 0.87 \\
\hline \multirow{4}{*}{$\begin{array}{l}\text { 2/10/2010: W National } \\
\text { Park with } 45 \mathrm{~mm} \text { of } \\
\text { rainfall }\left(\mathrm{DP}_{1} / \mathrm{DP}_{2}\right)\end{array}$} & \multirow{2}{*}{ Runoff } & $\mathrm{P}_{\mathrm{Fi}}$ & - & $0.895 \mathrm{~ns}$ & $0.204 \mathrm{~ns}$ & - & - & $0.582 \mathrm{~ns}$ & - \\
\hline & & $\mathrm{Vr}$ & - & 0.00 & 1.9 & - & - & 0.6 & - \\
\hline & \multirow{2}{*}{ Erosion } & $\mathrm{P}_{\mathrm{Fi}}$ & - & $0.845 \mathrm{~ns}$ & $0.178 \mathrm{~ns}$ & - & - & $0.487 \mathrm{~ns}$ & - \\
\hline & & $\mathrm{Vr}$ & - & 0.05 & 2.16 & - & - & 0.79 & - \\
\hline \multirow{4}{*}{$\begin{array}{l}\text { 6/10/2010: W National } \\
\text { Park with } 21 \mathrm{~mm} \text { of } \\
\text { rainfall }\left(\mathrm{DP}_{1} / \mathrm{DP}_{2}\right)\end{array}$} & \multirow[t]{2}{*}{ Runoff } & $\mathrm{P}_{\mathrm{Fi}}$ & - & $0.831 \mathrm{~ns}$ & $0.010^{*}$ & - & - & $0.094 \mathrm{~ns}$ & - \\
\hline & & $\mathrm{Vr}$ & - & 0.1 & 8.6 & - & - & 3.2 & - \\
\hline & \multirow[t]{2}{*}{ Erosion } & $\mathrm{P}_{\mathrm{Fi}}$ & - & $0.484 \mathrm{~ns}$ & $0.007^{* *}$ & - & - & $0.084 \mathrm{~ns}$ & - \\
\hline & & $\mathrm{Vr}$ & - & 0.73 & 10.04 & - & - & 3.42 & - \\
\hline \multirow{4}{*}{$\begin{array}{l}\text { 11/10/2010: W National } \\
\text { Park with } 11 \mathrm{~mm} \text { of } \\
\text { rainfall }\left(\mathrm{DP}_{1} / \mathrm{DP}_{2}\right)\end{array}$} & \multirow{2}{*}{ Runoff } & $\mathrm{P}_{\mathrm{Fi}}$ & - & $0.020^{*}$ & $0.003^{* *}$ & - & - & $0.249 \mathrm{~ns}$ & - \\
\hline & & $\mathrm{Vr}$ & - & 47.8 & 12.8 & - & - & 1.66 & - \\
\hline & \multirow{2}{*}{ Erosion } & $\mathrm{P}_{\mathrm{Fi}}$ & - & $0.325 \mathrm{~ns}$ & $0.025^{*}$ & - & - & $0.203 \mathrm{~ns}$ & - \\
\hline & & $\mathrm{Vr}$ & - & 1.67 & 6.11 & - & - & 1.96 & - \\
\hline \multirow{4}{*}{$\begin{array}{l}\text { 30/7/2010 Land use area } \\
\text { with } 27.5 \mathrm{~mm} \text { of rainfall and } \\
3 / 9 / 2010 \text { with } 27 \mathrm{~mm} \text { of } \\
\text { rainfall (Kargui \& Baru) }\end{array}$} & \multirow{2}{*}{ Runoff } & $\mathrm{P}_{\mathrm{Fi}}$ & - & $0.059 \mathrm{~ns}$ & $0.220 \mathrm{~ns}$ & - & - & $0.240 \mathrm{~ns}$ & - \\
\hline & & $\mathrm{Vr}$ & - & 15.5 & 1.9 & - & - & 1.7 & - \\
\hline & \multirow[t]{2}{*}{ Erosion } & $\mathrm{P}_{\mathrm{Fi}}$ & - & $0.020^{*}$ & $0.069 \mathrm{~ns}$ & - & - & $0.070 \mathrm{~ns}$ & - \\
\hline & & $\mathrm{Vr}$ & - & 48.6 & 3.8 & - & - & 3.76 & - \\
\hline \multirow{4}{*}{$\begin{array}{l}\text { 30/9/2010 Land use area } \\
\text { with } 27.5 \mathrm{~mm} \text { of rainfall } \\
\text { and } 14 / 8 / 2010 \text { with } \\
30 \mathrm{~mm} \text { of rainfall }\end{array}$} & \multirow{2}{*}{ Runoff } & $\mathrm{P}_{\mathrm{Fi}}$ & - & $0.749 \mathrm{~ns}$ & $0.166 \mathrm{~ns}$ & - & - & $0.757 \mathrm{~ns}$ & - \\
\hline & & $\mathrm{Vr}$ & - & 0.13 & 2.27 & - & - & 0.29 & - \\
\hline & \multirow{2}{*}{ Erosion } & $\mathrm{P}_{\mathrm{Fi}}$ & - & $0.901 \mathrm{~ns}$ & $0.345 \mathrm{~ns}$ & - & - & $0.299 \mathrm{~ns}$ & - \\
\hline & & $\mathrm{Vr}$ & - & 0.02 & 1.15 & - & - & 1.41 & - \\
\hline
\end{tabular}

Vr: Variance $\mathrm{P}_{\mathrm{Fi}}$ : Fisher Probability (of significance); ${ }^{* *}$ : $\mathrm{p}<0.01 ; *$ : $\mathrm{p}<0.05$; ns: not significant. -: data not available.

\subsubsection{Effect of the Site}

The site had a significant effect on runoff for the only episode common to all dongas studied $\left(\mathrm{Vr}=71 ; \mathrm{P}_{\mathrm{Fi}}=0.014\right)$. Indeed, the average runoff is twice as high at the land use areas level $(5.87 \mathrm{~mm})$ than at the park level $(2.32 \mathrm{~mm}$; l.s.d. $=1.81$ $\mathrm{mm}$, Figure 3). However, this factor had no effect on soil loss during the rainy episode of October 16, 2010. 


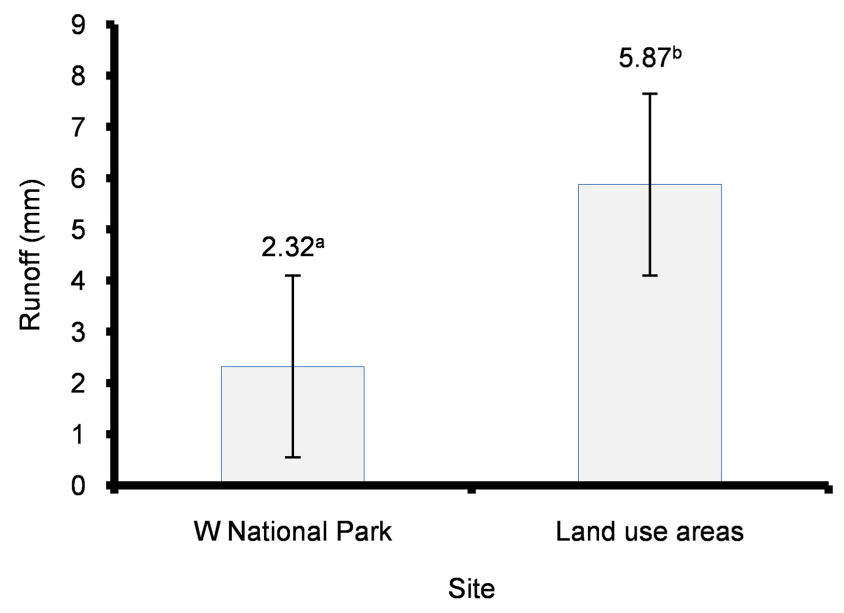

Figure 3. Effect of site on runoff at Karimama in 2010. (Error bar indicates standard error).

\subsubsection{Effect of the Level of Degradation of Dongas}

Overall, the level of degradation as well as the interactions between Sites, Donga and Topography do not influence runoff and soil loss on most of the rainfall events monitored. Average runoff varies from $4.55 \mathrm{~mm}$ to $7.4 \mathrm{~mm}$ and soil loss from 141 to $462 \mathrm{~g} \cdot \mathrm{m}^{-2}$. Variance analysis performed on the rainfall event data of October 11, 2010 shows significantly different runoff values from one level of degradation in Donga to another in $\mathrm{W}$ Park $\left(\mathrm{Vr}=47.8 \mathrm{P}_{\mathrm{Fi}}=0.020\right)$. Beginner dongas show a higher average runoff $(7.60 \mathrm{~mm})$ representing 1.34 times that of advanced dongas $(5.68 \mathrm{~mm}$; l.s.d $=1.19)$ (Figure $4(\mathrm{~A})$ ). The range of variation is $34 \%$.

Similarly, the rainy episodes of July 30 and September 3, 2010, showed quite contrasted soil losses in the land use areas (Figure 4(B); $\mathrm{Vr}=48.6 ; \mathrm{P}_{\mathrm{Fi}}=0.020$ ). The loss of land is higher in advanced dongas and is about 7 times that of the beginner dongas (236.74 $\mathrm{g} \cdot \mathrm{m}^{-2}$ versus $\left.34.15 \mathrm{~g} \cdot \mathrm{m}^{-2} ; 1 . \mathrm{s} . \mathrm{d}=125.2 \mathrm{~g} \cdot \mathrm{m}^{-2}\right)$.

\subsubsection{Effect of Topography}

For most of the studied rain events, topography has a significant effect on runoff and soil loss. The highest runoff values were recorded in the Center $(8.53 \mathrm{~mm})$ of the dongas (Figure 5(A)), while the lowest values were obtained in the Upstream $(2.41 \mathrm{~mm}$ ) (Figure $5(\mathrm{~B})$ ). The highest runoff increases are obtained on October 11, 2010 in the park (Figure 5(C)), with the highest runoffs in the Center $(8 \mathrm{~mm})$ and Downstream $(7.43 \mathrm{~mm})$. These results indicate that topography increases runoff by $65 \%$ and $78 \%$ in the Downstream and Central areas, respectively, compared to the Upstream $(4.50 \mathrm{~mm}$; l.s.d. $=1.71 \mathrm{~mm})$.

The rainy episode of October 16, 2010, which is the only one recorded at all sites and in all dongas $(\mathrm{p}=0.047)$, shows identical runoff values in both the Center and Downstream. In contrast, the situation in the Upstream differs significantly (Figure $5(B)$ ). Thus, runoff is twice as high in the Downstream than in the Upstream (5.24 $\mathrm{mm}$ versus $2.41 \mathrm{~mm}$; 1.s.d. $=2.32$ ).

Similarly, the highest soil losses are in the Center $\left(197 \mathrm{~g} \cdot \mathrm{m}^{-2}\right)$ followed by the 
Downstream $\left(147 \mathrm{~g} \cdot \mathrm{m}^{-2}\right)$. The highest increases in soil loss were observed during the rainy season of October 6, 2010 in W Park (Figure 5(D)). Soil loss is highest in the central donga $\left(197 \mathrm{~g} \cdot \mathrm{m}^{-2}\right)$ followed by Downstream $\left(147 \mathrm{~g} \cdot \mathrm{m}^{-2}\right)$. These results indicate that the topography increases soil loss by $146.25 \%$ in the Center and $83.75 \%$ in the Downstream, compared to the situation in the Upstream ( 80 $\mathrm{g} \cdot \mathrm{m}^{-2}$ l.s.d. $\left.=60.2 \mathrm{~g} \cdot \mathrm{m}^{-2}\right)$. The soil losses recorded during the rainy period of October 11, 2010 in the Center and Downstream are identical (Figure 5(E)).

\subsection{Site Interaction, Degradation Levels and Topography}

The results of the Three-Criteria Analysis of Variance show no significant effect of Site ${ }^{*}$ Donga, Site ${ }^{\star}$ Topography, Site ${ }^{\star}$ Donga ${ }^{\star}$ Topography interactions on runoff and soil loss (Table 2 ). These results indicate how complexity there is in the mechanisms explaining the processes of runoff and soil loss in the protected areas and land use areas. The average values of runoff vary from $4.10 \mathrm{~mm}$ to 7.4 $\mathrm{mm}$ and those of soil loss from $102.6 \mathrm{~g} \cdot \mathrm{m}^{-2}$ to $462 \mathrm{~g} \cdot \mathrm{m}^{-2}$ (Table 2).

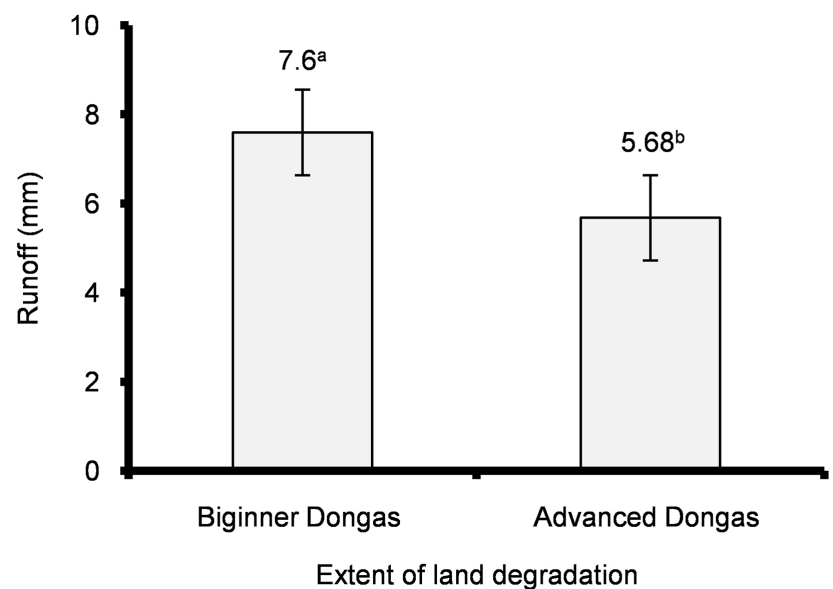

(A)

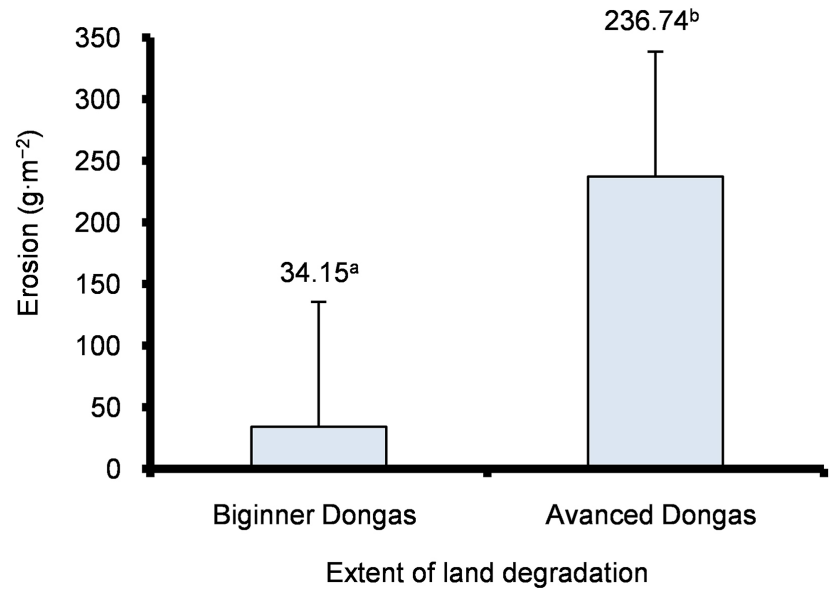

(B)

Figure 4. Effect of the extent of land degradation on the studied parameters: (A) runoff of 11/10/2010, (B) Soil erosion of 30 July and 3 September 2010 at Karimama district northern Benin. The error bar indicates the standard error. 


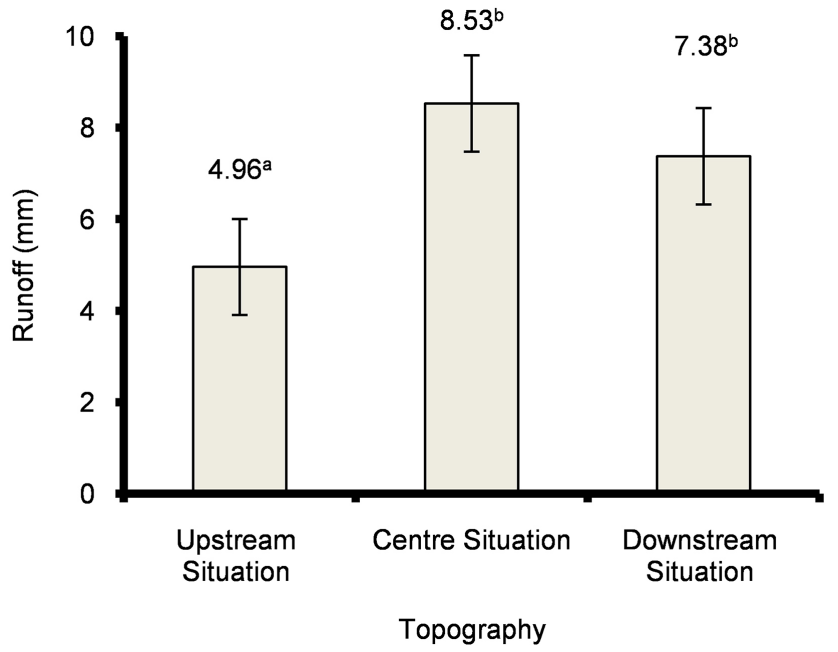

(A)

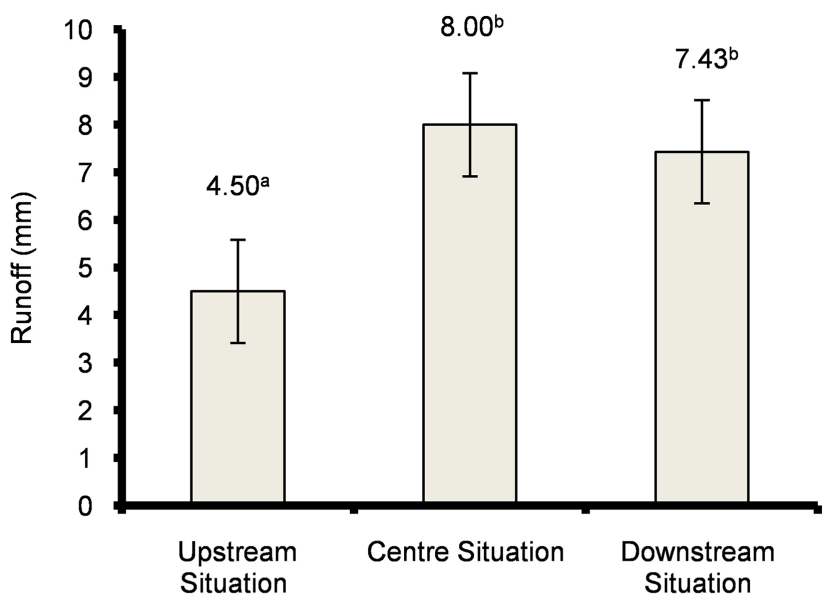

Topography

(C)

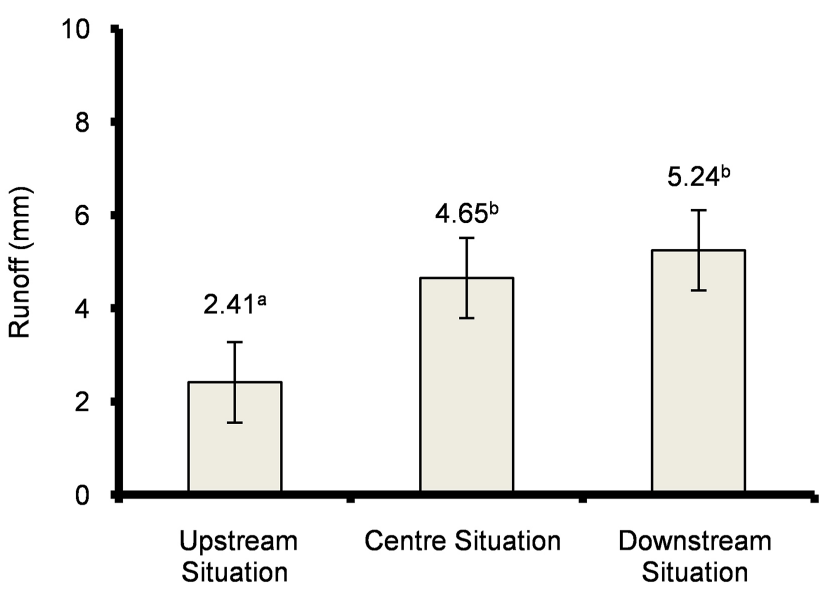

Topography

(B)

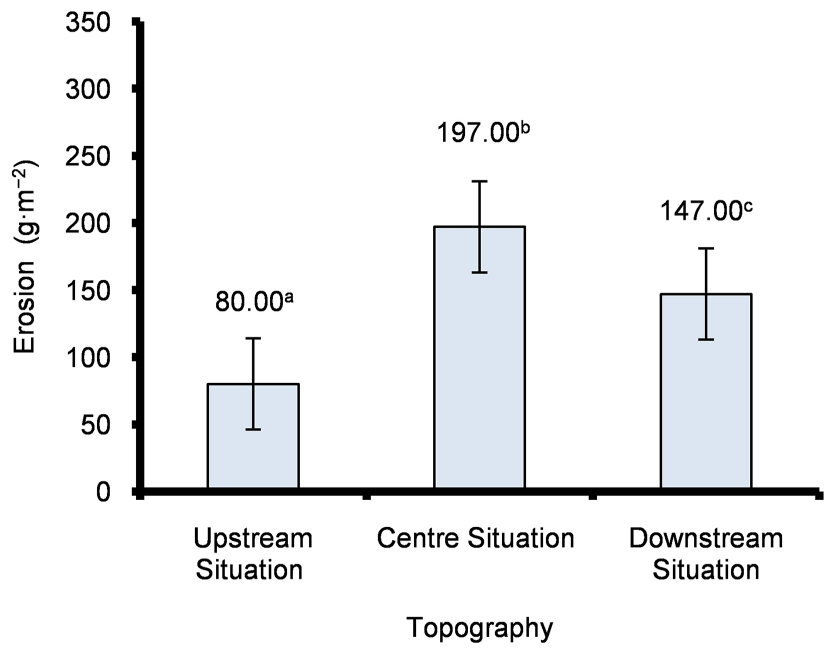

(D)

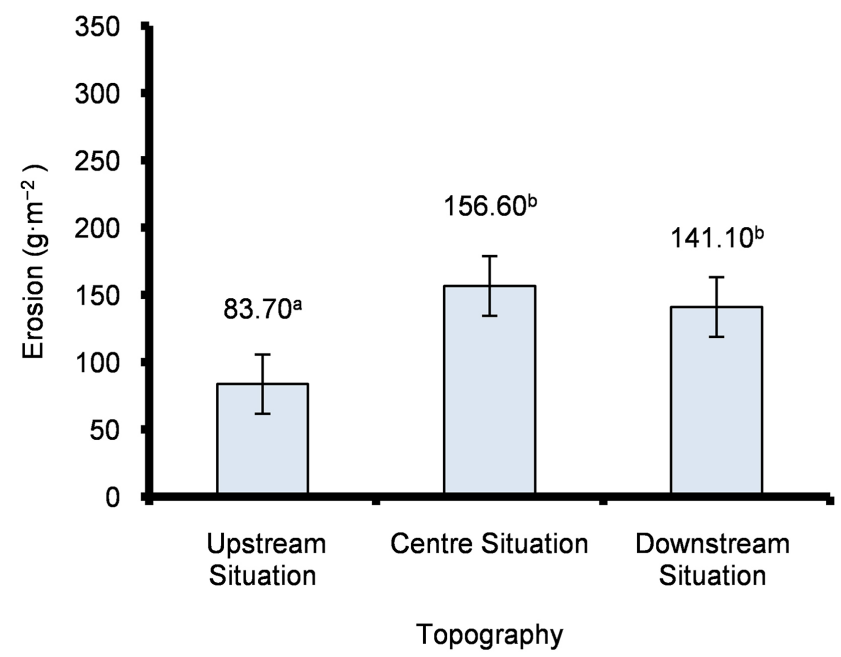

(E)

Figure 5. Effect of the topographical position on: the runoff (A) rain event of 06 October 2010, (B) rain event of 16 October 2010 and (C) rain event of 11 October 2010 and the topographical effect on soil erosion (D) rain event of 06 October 2010 and (E) rain event of 11 October 2010 at Karimama in northern Benin. 
Table 2. Effect of topography on erosion and runoff generated by the six studied rainfall events.

\begin{tabular}{|c|c|c|c|c|c|c|c|c|c|c|c|c|}
\hline \multirow[t]{2}{*}{$\begin{array}{c}\text { Topographical } \\
\text { position }\end{array}$} & \multicolumn{2}{|c|}{$\begin{array}{l}\text { Rainfall event of } 16 \\
\text { October 2010: All } \\
\text { Dongas in land use } \\
\text { areas with } 25 \mathrm{~mm} \\
\text { of rainfall and W } \\
\text { National Park with } \\
17 \mathrm{~mm} \text { of rainfaill }\end{array}$} & \multicolumn{2}{|c|}{$\begin{array}{l}\text { Rainfall event of } \\
2 \text { October } 2010 \\
\text { W National } \\
\text { Park Dongas } \\
\left(\mathrm{DP}_{1} \& \mathrm{DP}_{2}\right) \\
\text { With } 45 \mathrm{~mm} \\
\text { of rainfall }\end{array}$} & \multicolumn{2}{|c|}{$\begin{array}{l}\text { Rainfall event of } \\
6 \text { October } 2010 \\
\text { W National } \\
\text { Park Dongas } \\
\left(\mathrm{DP}_{1} \& \mathrm{DP}_{2}\right) \\
\text { With } 21 \mathrm{~mm} \\
\text { of rainfall }\end{array}$} & \multicolumn{2}{|c|}{$\begin{array}{l}\text { Rainfall event of } \\
11 \text { October } 2010 \\
\text { W National } \\
\text { Park Dongas } \\
\left(\mathrm{DP}_{1} \& \mathrm{DP}_{2}\right) \\
\text { With } 11 \mathrm{~mm} \text { of } \\
\text { rainfall }\end{array}$} & \multicolumn{2}{|c|}{$\begin{array}{c}\text { Rainfall events of } \\
30 \text { July } 2010 \text { and } 3 \\
\text { September } 2010 \\
\text { Kargui \& Baru land } \\
\text { use areas Dongas } \\
\text { with } 27.5 \text { et } 27 \mathrm{~mm} \\
\text { of rainfall }\end{array}$} & \multicolumn{2}{|c|}{$\begin{array}{c}\text { Rainfall events of } \\
20 \text { September } 2010 \\
\text { and } 14 \text { August } 2010 \\
\text { Kargui \& Baru land } \\
\text { use areas Dongas } \\
\text { with } 30 \mathrm{~mm} \\
\text { of rainfall }\end{array}$} \\
\hline & $\begin{array}{l}\text { Erosion } \\
\left(\mathrm{g} \cdot \mathrm{m}^{-2}\right)\end{array}$ & $\begin{array}{l}\text { Runoff } \\
(\mathrm{mm})\end{array}$ & $\begin{array}{c}\text { Erosion } \\
\left(\mathrm{g} \cdot \mathrm{m}^{-2}\right)\end{array}$ & $\begin{array}{l}\text { Runoff } \\
(\mathrm{mm})\end{array}$ & $\begin{array}{c}\text { Erosion } \\
\left(\mathrm{g} \cdot \mathrm{m}^{-2}\right)\end{array}$ & $\begin{array}{l}\text { Runoff } \\
(\mathrm{mm})\end{array}$ & $\begin{array}{l}\text { Eroion } \\
\left(\mathrm{g} \cdot \mathrm{m}^{-2}\right)\end{array}$ & $\begin{array}{l}\text { Runoff } \\
(\mathrm{mm})\end{array}$ & $\begin{array}{l}\text { Eroion } \\
\left(\mathrm{g} \cdot \mathrm{m}^{-2}\right)\end{array}$ & $\begin{array}{l}\text { Runoff } \\
(\mathrm{mm})\end{array}$ & $\begin{array}{l}\text { Eroion } \\
\left(\mathrm{g} \cdot \mathrm{m}^{-2}\right)\end{array}$ & $\begin{array}{l}\text { Runofft } \\
(\mathrm{mm})\end{array}$ \\
\hline Values of $\mathrm{P}_{\mathrm{Fi}}$ & $0.337 \mathrm{~ns}$ & $0.047^{*}$ & $0.178 \mathrm{~ns}$ & $0.204 \mathrm{~ns}$ & $0.007^{* *}$ & $0.010^{*}$ & $0.025^{\star}$ & $0.003^{* *}$ & $0.069 \mathrm{~ns}$ & $0.220 \mathrm{~ns}$ & $0.345 \mathrm{~ns}$ & $0.166 \mathrm{~ns}$ \\
\hline $\begin{array}{l}\text { Upstream } \\
\text { Situation }\end{array}$ & - & $2.41 \mathrm{a}$ & - & - & $80.00 \mathrm{a}$ & $4.96 a$ & $83.7 \mathrm{a}$ & $4.50 \mathrm{a}$ & - & - & - & - \\
\hline $\begin{array}{c}\text { Centre } \\
\text { Situation }\end{array}$ & - & $4.65 \mathrm{~b}$ & - & - & $197.00 \mathrm{~b}$ & $8.53 b$ & $156.6 \mathrm{~b}$ & $8.00 \mathrm{~b}$ & - & - & - & - \\
\hline $\begin{array}{l}\text { Downstream } \\
\text { situation }\end{array}$ & - & $5.24 \mathrm{~b}$ & - & - & $147.00 \mathrm{c}$ & $7.38 \mathrm{~b}$ & $141.1 \mathrm{~b}$ & $7.43 \mathrm{~b}$ & - & - & - & - \\
\hline Average & 102.6 & 4.10 & 140.00 & 6.2 & 141.00 & 6.96 & 127.3 & 6.64 & 135.00 & 4.55 & 462.00 & 7.4 \\
\hline
\end{tabular}

$\mathrm{P}_{\mathrm{Fi}}$ : FisherProbability (of signification); ${ }^{* *}$ : $\mathrm{p}<0.01 ;{ }^{*}: \mathrm{p}<0.05$; ns: non significatif; the average of runoff and soil erosion followed by the same letters are not statistically different at the $5 \%$ level.

\section{Discussion}

\subsection{Effect of the Site}

For the rainy episode of October 16, 2010 common to all sites, the high runoff in the soil compared to the park would come from multifactorial interactions, including: 1) Higher permeability in the Park W $\left(10.8 \mathrm{~cm} \cdot \mathrm{h}^{-1} \pm 7.2\right.$ versus $3.6 \pm 3.2$ $\left.\mathrm{cm} \cdot \mathrm{h}^{-1}\right)$. Indeed, high soil permeability leads to high water filtration due to the large pore volume [15]. This increase in infiltration leads to a decrease in runoff; 2) The steeper slope in the park $(3.0 \% \pm 1.3 \%$ versus $2.4 \% \pm 0.9 \%)$. There is evidence that runoff and soil loss increase with the length and degree of slope [16]. Indeed, according to the work of [4], runoff increases rapidly for small changes in slope inclination. However, land degradation is linked to poverty and human pressures, people's attitudes and values, poor land management, land tenure, and drought [17] which result in overgrazing, unsustainable agricultural activities, overexploitation of land [10] [18]. Degradation has increased desertification, decreased land productivity, and caused the loss of arable land [19]. Overgrazing, unsustainable agricultural activities that do not respect the environment and overexploitation of land destroy the vegetation cover causing bare soils favorable to erosion and soil degradation. These are factors favoring soil erosion and degradation.

The fact that the park and the land use areas are statistically identical in terms of soil loss but well discriminated on runoff would be relative to the low availability of materials likely to be eroded on the land use areas. Indeed, the tram- 
pling of animals and humans compacts the soil materials, obviously limiting their transport through the runoff. Moreover, this compaction limits the detachment of soil particles under the effect of rain. The result is low soil loss despite the high runoff in the village areas. This phenomenon has already been highlighted by [20]. Of course, soil crusting is a common phenomenon in semi-arid regions characterized by sparse vegetation and high rainfall intensities. It also affects certain cultivated soils sensitive to threshing. Surface crusting and its effect potential on runoff in a Sahelian context has been widely described [21] [22]. Surface crusts have a strongly limiting action with respect to infiltration due to the impedance effect exerted by their low hydraulic conductivity as well as by the desaturation of the underlying soil that they cause; in effect, the equivalent conductivity of the crust-soil system tends towards that of the underlying soil [23] but with an unsaturated value thus reduced. The in-situ measurement of the hydrodynamic properties of crusty soils is delicate [24] and, since the crusting is rarely uniform, it is difficile to find crusty zones of the same size as the field measuring devices. Runoff from partially encrusted surfaces is measured using visual observation grids and statistical approaches [25]. The effect of a surface crust on the infiltration is largely explained via models adapting the principle of Green and Ampt [26] [27] [28] [29]. In this context of heavy rains, within the plots used for our work, some surface crusting is noted. However, they deserve more attention in order to explain the effects of crusting on runoff and soil loss.

\subsection{Effect of the Level of Degradation}

Beginner dongas are distinguished from advanced dongas by the runoff essentially induced by a higher permeability $\left(20.8 \mathrm{~cm} \cdot \mathrm{h}^{-1} \pm 11.9\right.$ versus $9.2 \pm 5.4$ $\left.\mathrm{cm} \cdot \mathrm{h}^{-1}\right)$. Indeed, the slope and the covering are not very different. This high soil permeability, which is also due to the pore volume, allow high water infiltration. This increase in filtration leads to a decrease in runoff [30]. The high runoff in beginning dongas corresponds to a lower loss of soil. Beginning dongas behave like poorly developed soils for which runoff is high but soil loss is limited [31] [32]. This situation is believed to be due to the low availability of erosion-sensitive materials in beginning dongas. Indeed, the upstream crusting of the beating crust increases runoff while favoring the slow draining resistance of particles rearranged in a more compact manner [20]. This rearrangement would also serve as a resistance to detachment and availability of particles mobilized under the raindrops. Our observations are in agreement with this observation. Thus, the more advanced dongas are remarkable for the important loss of soil (making available the soil that can be dragged by the runoff water), and the less so are the beginner dongas.

\subsection{Effects of Topography}

\subsubsection{Effects of Topographical Positions}

The effect of slope on runoff is not yet clearly determined. Our results are not in 
agreement with those of [33] who, studying erosion on three levels of slope, finds an increase in the values of erosion from the top to the bottom of the slope. The difference observed between the Upstream and Downstream situations is due to the multifactorial interactions of which: 1) higher permeability in the Upstream than in the Downstream. The deposition in the Downstream, which is a finely drained fine element from the Upstream and the Center, is partly due to the differences in permeability observed due to the clogging of the pores by these elements. The high permeability in the Upstream would contribute to the reduction of the volume of water runoff. This is consistent with the theses that permeability, by promoting the infiltration of water into the soil, reduces runoff [20] [32] [34] [35]; 2) the lower slope at the headwaters is consistent with the results of [32] [36] [37] [38] which show that runoff increases with slope. They attribute this effect to the decrease in surface storage and depth of flaques. When the slope increases, the water layer present at the surface generally decreases but surface velocities increase. However, [39] observed a decrease in runoff with slope but for soils sensitive to the formation of crust and gullies as explained by [40]. [41] attribute this effect to the greater presence of gullies incising the crust, and thus increasing the infiltration, for the steepest slopes. On tropical soils in Thailand and Laos, other authors observe an increase in infiltration with slope [42] [43]. [42] also observes a decrease in runoff coefficient with slope for cultivated plots in Thailand, with slopes ranging from $16 \%$ to $63 \%$. It is therefore difficult to predict the slope effect which appears to be highly dependent on soil surface conditions.

\subsubsection{Effects Induced by the Same Topographic Position for Different Dongas}

The Upstream, Central and Downstream situations in the different dongas are statistically identical for most of the episodes studied. In fact, similar characteristics are observed there: low soil stripping, average vegetation cover overall, relatively low slope from one donga to the other. In addition, the rainy episodes of 30/7 and 3/9 on the one hand and 14/08 and 20/09 on the other hand in the land use areas of Kargui and Baru differ from each other due to the variation in rainfall intensity from one donga to another, which justifies the collapse of a large mass of soil. Such a collapse makes available a large mass of material easily carried by the runoff water. Average runoff and soil loss are $4.55 \mathrm{~mm}$ and 135 $\mathrm{g} \cdot \mathrm{m}^{-2}$ (30/7 and $3 / 9$ events) and $7.4 \mathrm{~mm}$ and $462 \mathrm{~g} \cdot \mathrm{m}^{-2}$ (14/8 and 20/9 events) (Table 2). For a $62 \%$ variation in runoff, the variation in soil loss is $242 \%$ with the rainy episodes of 14/8 and 20/9 at Kargui and Baru. These variations are due to the roughness of the soil surface which is, in general, characterized by the variance of altitudes. An increase in friction coefficient will cause an increase in water height and decrease flow velocities. The flow is directed by the microtopography of the site and will tend to concentrate by forming a drainage network. A microtopography organized parallel to the slope, for example, may then, by concentrating the flow, increase runoff. The distribution of water heights and 
flow velocities is therefore sensitive to the spatial variation of the microtopography [44]. In addition, further studies are needed to situate the respective effect of slope length, rainfall dynamics, vegetation and crusting on runoff and soil loss in dongas in Karimama.

\section{Conclusion}

This in-situ study of erosion allowed to quantify donga erosion in both W Park and its land use areas. Soil losses ranged from 0 to $2079.3 \mathrm{~g} \cdot \mathrm{m}^{-2}$ and runoff from 0 to $33.5 \mathrm{~mm}$ for rainfall between 7 and $60 \mathrm{~mm}$. The site response to runoff is significant for the single episode of October 16, 2010 common to all sites. For this episode, runoff was two time higher in the land use areas $(5.87 \mathrm{~mm})$ than the W Park $(2.32 \mathrm{~mm})$. Runoff and soil loss are globally higher in Downstream. Runoff is higher in the beginner dongas while soil loss is higher in the advanced dongas. The lowest runoff is observed in Upstream in W Park $(2.32 \mathrm{~mm})$ for the rainy season of October 16, 2010 and the highest in Central donga $(8.53 \mathrm{~mm})$. The average runoff varies from 4.10 to $7.4 \mathrm{~mm}$ while the average soil loss varies from 102.6 to $462 \mathrm{~g} \cdot \mathrm{m}^{-2}$.

\section{Acknowledgements}

This study was carried out with the financial and logistic support of the Laboratory of Applied Ecology, Faculty of Agronomic Sciences, University of Abomey Calavi (Republic of Benin) and the European Union (FP6 INCO-dev 031685) through the SUN Project (Sustainable Use of Natural Vegetation in West Africa). Karimama farmers have intensively collaborated in the collection of in situ data. Dr. Gouwakinnou Gérard commented on earlier versions of this manuscript.

\section{Conflicts of Interest}

The authors declare no conflicts of interest regarding the publication of this paper.

\section{References}

[1] Pimentel, D., Harvey, C., Resosudarmo, P., Sinclair, K., Kurz, D., McNair, M., Crist, S., Shpritz, L., Fitton, L., Saffouri, R. and Blair, R. (1995) Environmental and Economic Costs of Soil Erosion and Conservation Benefits. Science, 267, 1117-1123. https://doi.org/10.1126/science.267.5201.1117

[2] Meliho, M., Nouira, A., Benmansour, M., Boulmane, M., Khattabi, A., Mhammdi, N. and Benkdad, A. (2019) Assessment of Soil Erosion Rates in a Mediterranean Cultivated and Uncultivated Soils Using Fallout ${ }^{137}$ Cs. Journal of Environmental Radioactivity, 208-209, Article ID: 106021. https://doi.org/10.1016/j.jenvrad.2019.106021

[3] Panagos, P., Borrelli, P., Poesen, J., Ballabio, C., Lugato, E., Meusburgerb, K., Montanarellaa, L. and Alewell, C. (2015) The New Assessment of Soil Loss by Water Erosion in Europe. Environmental Science \& Policy, 54, 438-447. https://doi.org/10.1016/j.envsci.2015.08.012 
[4] Bewket, W. and Sterk, G. (2002) Farmers' Participation in Soil and Water Conservation Activities in Chemoga Watershed, Blue Nile Basin, Ethiopia. Land Degradation and Development, 13, 189-200. https://doi.org/10.1002/ldr.492

[5] Assefa, D.Z. (2009) Assessment of Upland Erosion Processes and Farmer's Perception of Land Conservation in Debre-Mewi Watershed, near Lake Tana Ethiopia. Thesis of Cornell University, Ithaca, $90 \mathrm{p}$.

[6] Hiepe, C. (2008) Soil Degradation by Water Erosion in a Sub-Humid West-African Catchment a Modeling Approach Considering Land Use and Climate Change in Benin. Thesis, ULB, Bonn, 337 p.

[7] Angima, S.D., Stott, D.E., O’Neill, M.K., Ong, C.K. and Weesies, G.A. (2003) Soil Erosion Prediction Using RUSLE for Central Kenya Highland Conditions. Agriculture Ecosystem and Environment, 97, 295-308.

https://doi.org/10.1016/S0167-8809(03)00011-2

[8] Toko, I. and Sinsin, B. (2008) Les phénomènes d'érosion et d'effondrement naturels des sols (dongas) du Parc National du W et leur impact sur la productivité des pâturages. Sécheresse, 19, 193-200.

[9] Avakoudjo, J. (2008) Dégradation des terres et réhabilitation des écosystèmes dégradés au Nord du Bénin: Etude de cas du Parc National du W et des terroirs riverains dans la Commune de Karimama (Bénin), DEA. Université d'Abomey-Calavi, Bénin, $68 \mathrm{p}$.

[10] Avakoudjo, J., Kindomihou, V. and Sinsin, B. (2011) Farmers' Perception and Response to Soil Erosion While Abiotic Factors Are the Driving Forces in Sudanian Zone of Benin. Agricultural Engineering Research Journal, 1, 20-30.

[11] INSAE (2003) Troisième Recensement Général de la Population et de l'Habitation (RGPH-3) Résultats définitifs: Caractéristiques générales de la population. Cotonou, Bénin, $404 \mathrm{p}$.

[12] Dennis, F., Martin, C., Grosso, J. and Morschel, J. (2006) Étude et cartographie de l'érosion des sols dans un vignoble du Sud Est de la France. Études de Géographie Physique, $\mathrm{n}^{\circ}$ XXXIII, UMR 6012 “ESPACE” du CNRS, Université de Nice-SophiaAntipolis. 23-32.

[13] Le Bissonnais, Y. (1996) Aggregate Stability and Assessment of Soil Crustability and Erodibility: I. Theory and Methodology. European Journal of Soil Science, 47, 425-431. https://doi.org/10.1111/j.1365-2389.1996.tb01843.x

[14] GenStat (2003) GenStat for Windows. Release 4.23DE Discovery Edition. VSN International Ltd., Hemel Hempstead.

[15] Mhazo, N., Chivenge, P. and Chaplot, V. (2016) Tillage Impact on Soil Erosion by Water: Discrepancies Due to Climate and Soil Characteristics. Agriculture, Ecosystems \& Environment, 230, 231-241. https://doi.org/10.1016/j.agee.2016.04.033

[16] Oliveira, A.H., da Silva, M.A., Naves, S.M.L., Curi, N., Neto, G.K. and de Freitas, D.A.F. (2013) Development of Topographic Factor Modeling for Application in Soil Erosion Models. In: Hernandez Soriano, M.C., Ed., Soil Processes and Current Trends in Quality Assessment, IntechOpen, London, 111-138. https://doi.org/10.5772/54439

[17] Olsson, L., Barbosa, H., Bhadwal, S., Cowie, A., Delusca, K., Flores-Renteria, D., Hermans, K., Jobbagy, E., Kurz, W., Li, D., Sonwa, D.J. and Stringer, L. (2019) Land Degradation. In: Climate Change and Land: An IPCC Special Report on Climate Change, Desertification, Land Degradation, Sustainable Land Management, Food Security, and Greenhouse Gas Fluxes in Terrestrial Ecosystems, Lund University Centre for Sustainability Studies, $184 \mathrm{p}$. 
[18] Avakoudjo, J. (2016) Evaluation des dongas: Processus, Gestion et Possibilités de mise en valeur dans la commune de Karimama au Nord du Bénin. Thèse de Doctorat en Sciences Agronomiques, Université d'Abomey-calavi, Bénin, 258 p.

[19] Eswaran, H., Lal, R. and Reich, P.F. (2001) Land Degradation: An Overview. In: Bridges, E.M., Hannam, I.D., Oldeman, L.R., Pening de Vries, F.W.T., Scherr, S.J. and Sompatpanit, S., Eds., Responses to Land Degradation, 2nd International Conference on Land Degradation and Desertification, Oxford Press, New Delhi, 20-35.

[20] Baron, S. (2008) Caractérisation de l'érosion hydrique sur le bassin de Rouffach (Haut-Rhin, Alsace) et conséquences sur le bassin d'Orage associé. Catena, 39, 11-31.

[21] Casenave, A. and Valentin, C. (1989) Les états de surface de la zone sahélienne. ORSTOM, 229.

[22] Valentin, C. and Bresson, L. (1992) Morphology, Genesis and Classification of Surface Crusts in Loamy and Sandy Soils. Geoderma, 55, 225-245. https://doi.org/10.1016/0016-7061(92)90085-L

[23] Akplo, T.M., Kouelo Alladassi, F., Houngnandan, P., Benmansour, M., Rabesiranana, N., Mabit, L., Ahoglé Agassin, M.A. and Alohoutadé, F.M. (2017) Effect of Tillage and Mulching on Soil Water Erosion in Linsinlin Watershed, Centre of Benin. Journal of Experimental Biology and Agricultural Sciences, 5, 515-524. https://doi.org/10.18006/2017.5(4).515.524

[24] Vandervaere, J., Peugeot, C., Vauclin, M., Jaramillo, R.A. and Lebel, T. (1997) Estimating Hydraulic Conductivity of Crusted Soils Using Disc Infiltrometers and Minitensiometers. Journal of Hydrology, 188-189, 203-223.

https://doi.org/10.1016/S0022-1694(96)03160-5

[25] Auzet, A., Poesen, J. and Valentin, C. (2002) Soil Patterns as a Key Controlling Factor of Water Erosion. Catena, 46, 85-87. https://doi.org/10.1016/S0341-8162(01)00159-X

[26] Ahuja, L.R. (1983) Modeling Infiltration into Crusted Soils by the Green-Ampt Approach. Soil Science Society of America Journal, 47, 412-418. https://doi.org/10.2136/sssaj1983.03615995004700030004x

[27] Parlange, J.Y., Hogarth, W.L. and Parlange, M. (1984) Optimal Analysis of a Surface Crust. Soil Science Society of America Journal, 48, 494-497. https://doi.org/10.2136/sssaj1984.03615995004800030004x

[28] Rawls, W., Brakensiek, D., Simanton, J. and Kohl, K. (1990) Development of a Crust Factor for a Green-Ampt Model. Transactions of the Asae, 33, 1224-1228. https://doi.org/10.13031/2013.31461

[29] Vandervaere, J.P., Vauclin, M., Haverkamp, R., Peugeot, C., Thony, J. and Gilfedder, M. (1998) Prediction of Crust-Induced Surface Runoff with Disc Infiltrometer Data. Soil Science, 163, 9-21. https://doi.org/10.1097/00010694-199801000-00003

[30] Roose, E., Dugué, P. and Rodriguez, L. (1992) La gestion conservatoire des eaux et des sols: Une nouvelle stratégie de lutte anti-érosive appliquée à l'aménagement de terroirs en zone soudano-sahélienne du Burkina Faso. Bois et Forêts des Tropiques, 233, 49-63.

[31] Diallo, D., Barthes, B., Orange, Q. and Roose, E. (2004) Comparaison entre stabilité des agrégats ou des mottes et risques de ruissellement et d'érosion en nappe mesurés sur parcelles en zone soudanienne du Mali Note de recherche. Sécheresse, 15, 57-64.

[32] N'guessan, Y.A., Adopo, K.L., Amani, E.M., Konan, K.B., Toure, M., Monde, S. and Aka, K. (2013) Etude bathymétrique, sédimentologique et environnement de dépôts 
des sables superficiels de la lagune de Fresco (Zone Ouest du Littoral Ivoirien). Journal of Asian Scientific Research, 3, 308-320.

[33] Ollesch, G. (2002) Influence of Time on Measurement Result of Erosion Plot Studies. Soil and Tillage Result, 67, 23-39. https://doi.org/10.1016/S0167-1987(02)00029-6

[34] Roose, E., Blancaneaux, P. and Freinas, P.L. (1993) Un simple test de terrain pour évaluer la capacité d'infiltration et le comportement hydrodynamique des horizons pédologiques superficiels: méthode et exemples. Cahiers Orstom Séries Pédologie, 28, 413-419.

[35] Bartley, R., Roth, C.H., Ludwig, J., Mcjannet, D., Liedloff, A., Corfield, J., Hawdon, A. and Abbott, B. (2006) Runoff and Erosion from Australia's Tropical Semi-Arid Rangelands: Influence of Ground Cover for Differing Space and Time Scales. $\mathrm{Hy}$ drological Processes, 20, 3317-3333. https://doi.org/10.1002/hyp.6334

[36] Römkens, M.J.M., Helming, K. and Prasad, S.N. (2001) Soil Erosion under Different Rainfall Intensities, Surface Roughness, and Soil Water Regimes. Catena, 46, 103-123. https://doi.org/10.1016/S0341-8162(01)00161-8

[37] Blavet, D., de Nonil, G., Roose, E., Maillo, L., Laurent, J.Y. and Asseline, J. (2004) Effet des techniques culturales sur les risques de ruissellement et d'érosion sous vigne en Ardèche (France). Sécheresse, 15, 11-20.

[38] Chaplot, V. and Le Bissonnais, Y. (2000) Field Measurements of Interrill Erosion under Different Slopes and Plot Sizes. Earth Surface Processes and Landforms, 25, 145-153.

https://doi.org/10.1002/(SICI)1096-9837(200002)25:2<145::AID-ESP51>3.0.CO;2-3

[39] Bradford, J. and Huang, C. (1992) Mechanisms of Crust Formation: Physical Components. Lewis Publishing, Ann Arbor, 55-72.

[40] Fox, D.M., Bryan, R.B. and Price, A.G. (1997) The Influence of Slope Angle on Final Infiltration Rate for Interrill Conditions. Geoderma, 80, 181-194. https://doi.org/10.1016/S0016-7061(97)00075-X

[41] Bryan, R. and Poesen, J. (1989) Laboratory Experiments on the Influence of Slope Length on Runoff, Percolation and Rill Development. Earth Surface Processes and Landforms, 14, 211-231. https://doi.org/10.1002/esp.3290140304

[42] Janeau, J.L., Bricquet, J.P., Planchon, O. and Valentin, C. (2003) Soil Crusting and Infiltration on Steep Slopes in Northern Thailand. European Journal of Soil Science, 54, 543-553. https://doi.org/10.1046/j.1365-2389.2003.00494.x

[43] Ribolzi, O., Bariac, T., Bresson, L., Dupin, B., Keooudone, K., Phanthavong, K., Richard, P., Thiebaux, J.P., Silvera, N., Soulilab, B., Valentin, C. and Vandervaere, J.P. (2004) Why Does Infiltration Rate Increase with Slope Gradient? Luang Phrabang, Laos.

[44] Esteves, M., Faucher, X., Galle, S. and Vauclin, M. (2000) Overland Flow and Infiltration Modelling for Small Plots during Unsteady Rain: Numerical Results versus Observed Values. Journal of Hydrology, 228, 265-282.

https://doi.org/10.1016/S0022-1694(00)00155-4 